\title{
Curricular innovation in the construction processes of university academics
}

\section{La innovación curricular frente a los procesos de construcción de los académicos universitarios}

ZEA-VERDÍN, Aldo A.†*, GONZÁLEZ-BASILIO, Sofia de Jesús, URIBE-OLIVARES, Nadia Sarahi and CASTELLON-LEPE, Alma Jazmín

\author{
Universidad Autónoma de Nayarit \\ ID $1^{\text {st }}$ Author: Aldo A., Zea-Verdín \\ ID1 ${ }^{\text {st }}$ Coauthor: Sofia de Jesús, González-Basilio \\ ID $2^{\text {nd }}$ Coauthor: Nadia Sarahi, Uribe-Olivares \\ ID $3^{\text {rd }}$ Coauthor: Alma Jazmín, Castellon-Lepe
}

DOI: $10.35429 /$ EJS.2020.12.7.11.17

Received February 15, 2020; Accepted June 29, 2020

\begin{abstract}
The processes of innovation faced by educational institutions are a response to the different demands in the political, economic and cultural fields of the socalled knowledge society and the complex reality it is experiencing. It is then that innovation becomes a fundamental element to modify or transform the educational and academic practices that are developed in these institutions and focuses directly on what the different agents do. When speaking of innovations in the university curriculum, it must be recognized that there are multiple elements to be considered in the reforms to which the curriculum is exposed and in the processes of construction of those who implement them in the different spaces of formation. This paper presents a compilation of theories on how to understand innovation, as well as a reflection on the processes of curricular innovation that have been carried out at the Universidad Autónoma de Nayarit.
\end{abstract}

Innovation, Curriculum, Academics

\begin{abstract}
Resumen
Los procesos de innovación los cuales afrontan las Instituciones Educativas son una respuesta a las diferentes demandas en el ámbito político, económico y cultural de la denominada sociedad del conocimiento y la compleja realidad que se vive. Es entonces que la innovación se convierte en un elemento medular para modificar o transformar las prácticas educativas y académicas que se desarrollan en dichas instituciones y se centra de forma directa en lo que realizan los diferentes agentes. Cuando se habla de innovaciones en el currículum universitario, se tiene que reconocer que existen múltiples elementos a considerar en las reformas a las que se expone éste y por ende en los procesos de construcción de quiénes las implementan en los diferentes espacios de formación. El presente artículo presenta una recopilación de teórica de como entender la innovación, además de una reflexión respecto a los procesos de innovación curricular que se han llevado a cabo en la Universidad Autónoma de Nayarit.
\end{abstract}

Innovación, Currículum, Académicos

Citation: ZEA-VERDÍN, Aldo A., GONZÁLEZ-BASILIO, Sofia de Jesús, URIBE-OLIVARES, Nadia Sarahi and CASTELLON-LEPE, Alma Jazmín. Curricular innovation in the construction processes of university academics. ECORFAN Journal- Spain. 2020. 7-12: 11-17.

* Correspondence to Author (E-mail: aldoverdin@ @otmail.com)

$\dagger$ Researcher contributing first author. 


\section{Introduction}

The social movements that directly afflict education have promoted actions and changes in the internal processes of educational institutions. This implies, in turn, a series of modifications in the expectations of training in the subjects, which become a series of strategies for innovation in the curriculum, focused on the generation of competent professionals to face and integrate the new challenges that today's society represents.

These new challenges in the training of future professionals are focused and specified in the curriculum, which is permanently subject to processes of updating, modification or, at its extreme, to radical reforms in its construction, achieving the above, implies or implies explicitly incorporate innovation as an inherent aspect in all processes and subjects participating in it.

It is necessary to recognize the implications of implementing innovation processes in the curriculum, since it not only has to do with responding to the different demands and needs of the social, political, economic and cultural sphere, but also in thinking about how academics build and capture these innovations.

As already mentioned, the Higher Education Institutions (HEIs) are in constant changes both in their structures and in their functions due to the demands of public policies and society itself. In the search for new processes, its primary actors try to have a clear vision of where it is expected to go and how to achieve it.

Although the subject of curricular innovation has already been addressed in various investigations, systematized in the State of Curricular Research in Mexico, the meaning that this particular reflection seeks to address is the appropriation made by subjects around innovation and the ways in which they position themselves in front of a discourse, which in many cases is not analyzed accurately in the university environment.

The objective of this article is to contribute to the understanding of the process of curricular innovation that takes place within public universities specifically in a State Public University (UPES), such as the Autonomous University of Nayarit, through theoretical reflection and from the perspectives of authors dedicated to explaining educational reality through the curriculum.

\section{The concept of curriculum versus innovation}

Starting from the concept of curriculum which is broad and questionable in different aspects, it has different meanings in the educational field. It is assumed as the main mechanism for the transmission of culture and from it the knowledge that society as a whole needs to know and develop is selected and integrated.

The curriculum understood as a product or as a process, indicates the participation of academics and students in the construction and operation of the curriculum project. The curriculum as a process and as a social practice can also be understood in terms of Alicia de Alba (1991) as a political-cultural project that synthesizes knowledge, values, beliefs, habits and customs, and integrates different and diverse interests, sometimes contradictory.

These conceptualizations allow us to approach a posture of the curriculum oriented to the construction of the participating agents and as a project that is developed from educational and social practices that have to be consolidated in training processes linked to the needs and positions of academic agents.

From the above, it can be said that, innovating in the curriculum starts or should start from changes in its structure, determination of new directions for professional training, definition of new academic roles, development of new and varied forms of participation among university groups, establishment of new forms of organization, among others. But these changes must be mediated in the participation of university academics.

The depth of the process of social change currently taking place rests with those who assume the responsibility of training the new generations (Aretio, Corbella and Figaredo, 2007). The new educational processes require the participation of various actors, in this case reference is made to university academics, who from different professional roles contribute to this transformation of institutions through the integration of social changes in the curriculum.

Contreras (1994) mentions that, although not all changes within the curriculum mean an innovation process for an institution, the truth is that the vast majority of modifications are thought with that intention (p. 3), which refers to the importance of institutions integrating the concept of innovation into the curriculum as a permanent element, leading to quality in both content and teaching. 
Therefore, understanding that the change in the curriculum has to do with the modification of social practices and for them to be reflected in it, it is necessary to perceive its implications (Ibidem, 1994, p. 5), therefore, is great importance a study of the desired situation, a balance between the real and the possible.

\section{Integration of the concept of innovation from the university curriculum}

Education has undergone significant changes in recent decades, so institutions would be expected to transform. Guzmán and Nahón (2016) express that universities have a social responsibility to make educational changes that allow their community to adopt the best valued skills. Institutions need to carry out optimal, controlled and reproducible transformations in order to promote and control the processes of production of intangible capital in education.

It is recognized that universities not only have to do things differently, if not better, thus referring to the concept of innovation. In other words, you can only understand innovation in institutions when you want to carry out a wellfounded process of change. That they generate viable and practical changes that are thought from an improvement perspective (Zabalza, 2004). In the field of education, the term innovation is a new concept, from which various discourses related to educational reforms and changes are structured (Gros and Lara, 2009; Orozco, 2010 and Díaz, 2014), therefore, is used in various ways from basic, upper secondary and higher education, with very specific and significant meanings for each context, which turn out to be very heterogeneous.

In this sense, innovation must be understood as a process that has to be applied intentionally and in advance, educational actors must be recognized as an essential element to manage change processes. Fullan (2007) mentions that for the processes of change to be possible, it is necessary to have a comprehensive vision of the factors that intervene in it and emphasizing the sense that academics attribute to it. Innovation is emphasized in the field of the curriculum, since it represents a strategy of higher education institutions to face social changes and legitimize their role as trainer of professionals capable of facing the diverse demands (labor, personal, ideological, among others) that modern society manifests, the current society in which one lives is subject to a quantity of information, which increases day by day and therefore the formation of subjects becomes a real challenge for educational institutions.
These new information parameters respond to the main evolution of the community; the knowledge society. Which is not considered a static presence, neither finished nor defined. In this regard, Carneiro (2000, p. 41) mentions that "in the new, unstable, inventive and innovative society, the project overcomes the memory, the future dominates the past, the models are constantly questioned" so that talking about innovation that involves facing the dynamism of the knowledge society should not be assumed as a question with an end.

Incorporating changes in the knowledge society into the curriculum implies a slow pace. Formal and scholastic education in general in its different types and educational levels, maintains a slow trend of updating its processes and contents compared to the growth of social demands and the complexity of the problems to which the institutions seek to pay. It is then that innovation is more than improving, it implies generating a real change, a certain amount of risks and openness to results that are not expected and to processes that can arise in an improvised way.

Based on the above, the processes of resignification and appropriation of university academics to understand the complexity of educational and curricular innovation, is essential for them to be carried out, as well as thinking in this field. they produce tensions, conflicts, interest games, expectations, alliances and commitments. Where the total transformation of what was planned is not always reached, but without a doubt something new is introduced, different in what ordinarily worked (Díaz Villa and Nieto, 2012).

Recognizing the action of academics within institutions and remembering that innovation is subject to constant modifications and variations since it takes place in contexts characterized by their own dimensions and social expressions, the perspectives and experiences of university academics, are elements to consider in the approaches they make from the design and development of the curriculum.

It is then that innovation requires being viewed as a profound need for change that has to do with paradigms, social and educational practices in a specific community and "as a product of the reflection and appropriation of the people involved in the process (Díaz, 2005 . p. 43), where universities have to be entities of transition between social changes and educational processes. 
The innovation discourse around education must be one of constant reinvention, the critical adoption of generating through a constant deconstruction of reality (Díaz, 2009).

\section{Innovations in the curriculum and educational reforms in universities}

The ability of the university to structure proposals whose scope affects the order of the social structure, is one of the main elements to focus attention on its activity and the processes that take place within; One of these processes refers to the construction of curricular projects and is conceptualized in the university curriculum where the formation of subjects represents the synthesis of cultural elements that hegemonic groups determine for a professional practice (Alba, 1991).

In universities, the design and development of curricular projects takes a significant weight in the construction of the proposals on which university professionals will be trained, from this idea the curriculum as mentioned by Díaz (2013) becomes the main mechanism to structure the university project.

In Mexico, educational reforms are not exempt from the political and economic pressures that make higher education institutions propose processes of "change with absence" (De Alba, 1991) of processes of reflection on the social conditions that determine the university. and even more, without an analysis of the institutional conditions and the educational system that will allow or not the viability of the reforms that are undertaken.

It is important to mention that an educational reform differs from curricular innovation in the strict sense, but both can be part of the same process. In this regard, Navarro and Sánchez (2004) mention that the reform involves planned changes in the entire structure of the institution, while the innovation integrates a set of changes planned on a smaller scale and that are part of a larger organizational structure.

The analyzes of the educational reform processes in the world, coincide that the transformations, reforms and innovations of the educational systems must attend to the teaching needs and the training of the academics as agents of change (Zidán, 2006). The innovation-led reform processes must be carried out collectively, that is, they allow all the various common points to be articulated. In the same way, the authors express that the impossibility of understanding reality allows the consolidation of inherited educational models (Lanz, Fergusson and Marcuzzi, 2003).
Innovation is then a central element of the curricular reform processes both in the design and development of the curriculum. If we start from the concept of curriculum development by Gimeno Sacristán (2008), innovation is the product of the participation of university agents. From this idea, the educational reform integrates a curricular reform, where the collaboration of the academics is something inherent when determining the curricular project within the institution.

According to Diaz (2005), the notion of curricular innovation is taken as a way of incorporating educational novelties into the curriculum, this process in most cases carried out without any reflection on institutional-academic, management, financial, among others- that could enable them or not. The author establishes that teachers are placed as the last ones responsible for developing such innovations, that is, as the actors in a scenography outlined by the central administration and that on rare occasions success is recognized as part of that teaching activity.

Generating the processes of change within the meaning of the universities is not an easy task, therefore, it must be based on elements that support them. Lanz, Fergusson and Marcuzzi, (2003) express elements that give a guideline to the generation of transformation processes in the university curriculum, such as the social relevance referred to the adaptations to specific economic, social and political demands, democracy, translated into the idea and practice of a university government that integrates the perspectives of its educational actors and critical thinking through the exercise of reflection from the plurality.

\section{Results and contributions: the institutional context and the management of curricular innovation}

Specifically in the case of the Autonomous University of Nayarit, in 2003 an academic reform process marked by curricular innovation was undertaken, which brought with it a series of changes in training processes and forms of academic organization; Most of these approaches were left without operation and far from materializing in specific practices, among them: organization by academic areas, the operation of training processes through academic bodies and multi, inter and transdisciplinary training (UAN, 2003).
ZEA-VERDÍN, Aldo A., GONZÁLEZ-BASILIO, Sofia de Jesús, URIBE-OLIVARES, Nadia Sarahi and CASTELLONLEPE, Alma Jazmín. Curricular innovation in the construction processes of university academics. ECORFAN Journal- Spain. 2020 
The change process required activities by university academics dedicated to innovation. The university curriculum became the main axis of the academic reform of the institution and on the innovation process, other activities changed, among them the incorporation of tutorials, the flexibility of training times and the inclusion of the competency-based approach.

Between 2011 and 2014, the university redesigned more than $85 \%$ of its Associate Professional and Bachelor's degree plans, taking up the results of an institutionally relevant study that was carried out given the need to innovate earlier in the current context.

It is from this process that advances in innovation can be identified with respect to the construction of study plans; however, absences can also be seen in the curricular designs that will affect the training results of university professionals.

In a balance of those carried out, it can be said that the process of curricular innovation allowed the institution, in the first instance, to modify the study plans regarding the incorporation of elements of flexibility in the training areas that constitute school careers, updating the reference social problems; and focus the training process on students, as well as incorporate integrated professional competences (Farfán et al, 2010) as a unit for achieving the educational process (UAN, 2014).

For the development of the curricular redesign process that was undertaken at the university, a guide called Methodology for the design of curricular projects for integrated professional competencies was prepared (González and Zea, 2011), the purpose of which was to become a support for the group of academics responsible for the redesign and academic groups that made up the curricular committees. In addition, a series of institutional advisory services were provided to the different educational programs for the development of this process.

More than ten years after the reform carried out in 2003 and eight years after the 2012 modification, a series of curricular innovations have emerged at the institutional level, such as: incorporation of transversal axes, university collaboration projects, intermediate evaluation process, without They will undoubtedly have a profound impact on study plans and programs, but like any change it will improve and strengthen the development of the curriculum and therefore the training of professionals in different areas of knowledge.
However, and despite the efforts made to continue on this path of innovation, there are no studies within the institution that allow us to identify the level of scope of the innovations that were explicitly proposed to the curricular projects and, on the other hand, the changes cannot be valued as an isolated and individual fact, but on the contrary, it must become more complex from what the innovation implied for the academics the design process and the way in which they develop it.

Knowing how it was carried out and the way in which innovation is developed, will allow us to understand the processes from which the subjects appropriated or not their own.

Likewise, recognizing the main elements that shaped the process of curricular modification at the university in 2011 and 2014, will allow us to understand the construction processes of teachers in the face of curricular innovation, and this will provide guidelines for reflecting on how these same academic agents will have to re-incorporate these proposals designed from and for innovation not only in design but also in the development of study plans and programs.

It should be mentioned that the conceptualization of each of these forms of curricular innovation should not be problematized, but rather from the way in which these efforts are part of an innovative project that university academics undertook and are currently developing, and therefore Therefore, the gaze must turn around the sense of construction of university teachers against institutional curricular innovations.

Understanding that academics build different positions regarding the curricular innovation processes that they design and develop, and that these are related to tension, organizational and identity processes that are revealed, its analysis is indisputable.

\section{References}

Aretio, L. G., Corbella, M. R., \& Figaredo, D. D. (2007). De la educación a distancia a la educación virtual (p. 303). Ariel

Barriga, F. D. (2009). TIC y competencias docentes del siglo XXI. Los desafíos de las TIC para el cambio educativo, 139.

Carneiro, R. (2000). Sentidos, Curriuculum y docentes. Recuperado de http://bibliotecavirtual.clacso.org.ar/Argentina/l pp/20100324023943/12.pdf 
Contreras Domingo, J. (1994). Enseñanza, currículum y profesorado. Introducción crítica a la didáctica. Madrid: Akal.

Corvalán O. y Montero P. (2013). Seguimiento y contexto de proyectos de innovación curricular en entornos de políticas de educación superior. En O. Corvalán, J. Tardif y P. Montero (Coords), Metodologías para la innovación curricular universitaria basada en el desarrollo de competencias (pp.259-276). México: ANUIES.

De Alba, A. (1991). Currículum: crisis, mito y perspectivas. México, DF: UNAM.

De Alba, A. (1991). Evaluación curricular. Conformación conceptual del campo. México, DF: UNAM.

De Alba, A. (2007). Currículum-sociedad. El peso de la incertidumbre, la fuerza de la imaginación. México: IISUE.

De Alba, A. (2010). Currículum-sociedad. El peso de la incertidumbre, la fuerza de la imaginación. México: IISUE UNAM.

De Ibarrola, M. (2012). Experiencias y reflexiones sobre el diseño y la evaluación curricular. En M. Landesmann. (Coord.), El curriculum en la globalización A tres décadas del currículum pensado y el curriculum vivido (pp.15-22). México: UNAM.

Díaz Barriga, A. \& García, G. J. (2014). Desarrollo del currículum en América Latina. Lo que aprendimos. En A. Díaz-Barriga \& J. García (coords.), Desarrollo del curriculum en América Latina. Recuperado de file://C:/Users/Jazm\%C3\%ADn\%20PC/Downl oads/Desarrollo\%20del\%20curriculum $\% 20 \mathrm{en} \%$ 20Am\%C3\%A9rica\%20Latina_imprenta(15)\% 20Copy.pdf

Díaz Barriga, A. (2015). Currículum: entre utopía y realidad. Argentina: Amorrortu editores.

Díaz Barriga, A. F. (2013). Innovaciones curriculares. En A. Díaz Barriga. (coord.), La investigación curricular en México 2002-2011, (109-179). México: ANUIES, COMIES.

Díaz, M., \& Nieto, L.M. (2012). Del concepto de innovación. [Con]textos, 1(4), 39-53.

Díaz-Villa, M. (2013). Currículum: debates actuales. Trazos desde América Latina. [Contextos, 2(8), 21-33. Recuperado de http://revistas.usc.edu.co/index.php/Contextos/a rticle/view/356\#.VlUa1nYvfIU
Flores, T. G., \& Nahón, A. E. (2016). Proceso de diseño de un modelo de educación a distancia como estrategia de innovación educativa para la Economía del Conocimiento. Edutec. Revista Electrónica de Tecnología Educativa, (55), 330.

Fullan, M. 2007. The new meaning of educational change. 4 th ed. New York: Teachers College Press

Gimeno S. (2010). El currículum en la sociedad de la información y del conocimiento. En J.

Gimeno Sacristán. (Comp.), Saberes e incertidumbres sobre el currículum (pp. 180202). Madrid: Morata.

Gimeno, S. (2013). El curriculum: una reflexión sobre la práctica. Madrid: Morata. (Año de publicación del libro original, 1988, 10ma edición).

González, B. \& Zea, V. (2011). Metodología para el diseño de proyectos curriculares por competencias profesionales integradas (documento de trabajo). Recuperado de http://www.uan.edu.mx/d/a/sd/dpe/_metod_dise no_proectos_curric_compet.pdf

Lanz, R., Fergusson, A., \& Marcuzzi, A. (2003). Procesos de reforma de la educación superior en América Latina. Instituto Internacional para la Educación Superior en América Latina y el Caribe (Iesalc). Informe Sobre La Educación Superior en América Latina y el Caribe, 2005, 105-111.

Minakata, A. (2009). Las estrategias de gestión de las innovaciones: entre lo prescrito, lo deseable y lo posible. En M. E. Chan (Coord.), La gestión de la innovación en el marco de las reformas educativas (pp. 145-158). México: ITESO.

Ruiz, L. (2009). Propuesta de un modelo de evaluación curricular para el nivel superior. Torres, J. (2011). La justicia curricular. El caballo de Troya de la cultura escolar. España: Morata.

Torres, J. (2003). El curriculum oculto. Madrid, España: Morata (año de publicación del libro original, 1991, 7ma edición).

Universidad Autónoma de Nayarit, (2014). 4to. Informe de labores. Recuperado de http://informe.uan.mx/2014/d/4to_Informe_CO MPLETO.pdf 
Universidad Autónoma de Nayarit. (2003). Documento Rector. Recuperado de http://www.uan.edu.mx/d/a/sg/Legislacion/dcf4 .pdf

Universidad Autónoma de Nayarit. (2012). UAN-PAC (Informe de actividades).

Zabalza, M. Á. (2004). Innovación en la enseñanza universitaria. Contextos Educativos. Revista de Educación, (6), 113-136.

Zidán, E. R. (2006). Reforma de la educación superior en América Latina. Algunas reflexiones sobre calidad de la enseñanza universitaria, formación del profesorado y las reformas institucionales actuales a partir del análisis del debate en la universidad uruguaya. Unipluriversidad, 6(2), 85-98. 